\title{
DEMOCRACIA E TOTALITARISMO: ANOTAÇÕES SOBRE DEMOCRACIA, SEPARAÇÃO DOS PODERES E FEDERALISMO
}

\section{DEMOCRACY AND TOTALITARIANISM: NOTES ON DEMOCRACY, SEPARATION OF POWERS AND FEDERALISM}

\begin{abstract}
Fernando de Brito Alves ${ }^{1}$ Yago Aparecido Oliveira Santos ${ }^{1}$

Recebido em: 27/07/ 2016 Aceito em: 06/07/2017

fernandobrito@uenp.edu.br yagoapoliveira@gmail.com

Resumo: O presente trabalho trata de breve investigação quanto aos problemas da efetivação da democracia nas sociedades modernas. Será realizado um estudo por uma perspectiva jurídica e política, através de uma cisão conceitual, aplicando-se, também à ideia de democracia, ao se analisar os problemas para a sua plena aplicação. Ao final, se buscará investigar quais instrumentos possibilitam a plenitude da democracia, através de uma conciliação entre a democracia jurídica e a democracia política, a partir de uma perspectiva crítica quanto aos modelos de limitação do Estado.

Palavras-chave: Estado. Democracia. Separação dos Poderes. Federalismo.

Abstract: This paper deals with brief investigation of the problems of realization of democracy in modern societies. There will be a study for a legal and political perspective, through a conceptual split, applying also to the idea of democracy, when analyzing the problems for its full implementation. Finally, it seeks to investigate which instruments allow the fullness of democracy through a reconciliation of legal democracy and political democracy, from a critical perspective regarding the state limitation models.
\end{abstract}

Keywords: State. Democracy. Separation of Powers. Federalism.

\section{INTRODUÇÃO}

A democracia é, sobretudo, um valor fundamental a ser preservado. Contudo, uma análise factual da sociedade leva à constatação de que, quando diante de um Estado que não possui por interesse primeiro a proteção desse valor, a soberania do povo passa a não ter efetividade. Com isso, a democracia fica relegada ao mero interesse do Estado, que, em uma análise consequencialista, realiza um juízo de conveniência para aferir a sua aplicabilidade. É preciso que se transcenda essa análise factual, investigando quais as causas sociais e jurídicas que originam esse problema.

Isto porque, diante da ineficiência política da democracia, o poder político passa a modular o poder jurídico, afetando diretamente a sua eficácia. Uma vez que esse poder político resulte de uma estrutura que não corresponda àquela que reflita os interesses sociais, a democracia resta totalmente afetada, pois o poder político que rege o Estado não será mais exercido pelo povo.

Verifica-se que o Estado, assim como a democracia, pode ser divido em dois polos que se correlacionam: o polo jurídico e o polo político. Quando esses dois polos se relacionam de forma harmônica é possível defender a existência de uma democracia plena, fortalecida tanto em seu aspecto político, quanto em seu aspecto jurídico. Contudo, em caso de divergência entre eles, a plenitude da democracia e a supremacia do direito restam prejudicadas.

\footnotetext{
${ }^{1}$ Universidade Estadual do Norte do Paraná - UENP - Jacarezinho - Paraná - Brasil
} 
Diferenciar a democracia jurídica da democracia política passa a ser essencial ao se compreender que, enquanto a democracia jurídica institucionaliza a democracia política, esta última delimita a aplicação dos preceitos democráticos legalmente previstos. É, inclusive, possível que o Estado político reprima a aplicação da democracia jurídica de tal modo que esta se torne ineficaz, propiciando a instituição de um regime totalitário, ainda que sob a vigência de um ordenamento jurídico democrático.

A consciência de tal processo ressalta a necessidade de medidas que visem consolidar a democracia em sua completude, com o fortalecimento do acesso popular ao Estado e ao direito, a fim de que haja um controle constante sobre a atuação estatal na observância dos preceitos democráticos.

Faz-se necessário investigar a razão para a divergência entre o "jurídico" e o "político", bem como os mecanismos a serem construídos e aprimorados para que se evite tal desarmonia.

\section{ESTADO E DEMOCRACIA: DISSONÂNCIAS ENTRE O POLÍTICO E O JURÍDICO}

Inicialmente, é preciso investigar no Estado as razões para a dissonância entre a democracia em seu aspecto político e em seu aspecto jurídico, haja vista que é na formação desse Estado a maior manifestação dessa bipolarização.

Para a formulação dessa ideia, é importante a construção teórica de Carl Schmitt, a partir da qual pode se verificar que o sistema jurídico estatal é continuamente afetado pelo aspecto político do Estado.

Por outro lado, a equivalência estatal = político mostra-se incorreta e enganosa, na mesma medida em que Estado e sociedade se interpenetram, todos os assuntos até então políticos tornam-se sociais e vice-versa, todos os assuntos até então "apenas" sociais tornam-se estatais, como ocorre, necessariamente, numa coletividade democraticamente organizada. As áreas até então "neutras" - religião, cultura, educação, economia - deixam então de ser "neutras" no sentido de não-estatal e não-político (SCHMITT, 1992, p. 47).

Se infere a partir dessa ideia que, a nível conceitual, é possível realizar uma divisão do Estado entre os polos jurídico e político. É nesse aspecto que, diante de Carl Schmitt, se tem que o poder político exerce uma grande influência no poder jurídico estatal e, de certa forma, o modula, adequando-o aos fins que the sejam convenientes.

No pensamento de Schmitt, não se compreende o direito como reprodução automática das competências normativas. O direito é situacional. O poder é maior que o seu momento normativo. Para Schmitt, ao contrário do pensamento de Kelsen, não há identificação entre Estado e direito. Na visão 
kelseniana, a competência do poder estatal é a competência que formalmente as normas Ihe atribuem. Para Schmitt, o fenômeno do poder é maior que o do direito. Por isso, a guerra, a exceção, a ditadura, o caso extremo, revelam a verdade jurídica, não contida nos limites da norma jurídica (MASCARO, 2013, p. 61).

Paulo Bonavides (2012, p. 348) ensina que a Constituição pode ser vista a partir de uma visão jurídica ou de um ponto de vista político, posto que toda Constituição é representada por essas duas dimensões:

Toda Constituição tem duas dimensões: uma jurídica, outra política. Mas autores como Lassale e Jellinek, exprimindo a fadiga e a exaustão do formalismo positivista, bem como a ineficácia da Constituição escrita perante o fático e o real, levaram seu ressentimento crítico à uma extremidade oposta, ao levantarem a tese de que na origem e na essência as questões constitucionais eram e continuam sendo questões de poder e não questões jurídicas, com todas as consequências que deste entendimento errôneo advém para o Direito Constitucional, tido não mais por ciência do dever-ser e do normativo ("sollen"), mas unicamente do ser, da realidade, do existencial ("sein").

Com isso, se passa a investigar as características dessa bipolarização, para posteriormente se compreender as consequências geradas em razão da institucionalização de mecanismos que visem a unificação desses dois polos.

\subsection{O ESTADO POLÍTICO}

Nos Estados modernos não se torna possível verificar de forma clara uma divisão entre o caráter jurídico do Estado, e o seu caráter político. Isso ocorre em razão do fato de que em referidos Estados, há o consenso de que esses dois polos devem convergir, ou seja, devem se voltar ao mesmo fim.

A conversão desses polos ao mesmo fim nada mais significa do que a consecução de objetivos pré-definidos. Em uma democracia, o Estado, tanto em seu aspecto político, quanto em seu aspecto jurídico, deve estar alinhado a realização dos interesses do povo, haja vista que é a soberania popular característica da democracia. Em uma ditadura, o Estado, politicamente e juridicamente, se alinha para a consecução dos fins que interessam aos seus soberanos, que ocupam os cargos de direção do próprio Estado.

Como ensina Schmitt (1992, p.19), logo ao iniciar o seu livro O Conceito de Político, "o conceito de Estado pressupõe o conceito de Político". Ou seja, inviável analisar o Estado sem uma investigação quanto aos pressupostos políticos que lhe garantem sua formação.

Revista do Direito [ISSN 1982-9957]. Santa Cruz do Sul, v. 1, n. 51, p. 3-35, jan./abr. 2017. https://online.unisc.br/seer/index.php/direito/index 
Vale lembrar, com apoio de Bonavides (2014, p. 184), que todo o Estado é ao mesmo tempo poder, ou manifestação de um poder, sendo que a distribuição desse poder determinará o regime político para o qual o Estado se voltará:

Todo Estado, em sua essência e substantividade, é poder, como diz o publicista alemão Forsthoff. Não se pode encobrir esse fato, nem se deve ignorá-lo. As formas como esse poder se manifesta ou a maneira como ele se distribui, estas, sim, diferem, conforme se trate de poder de um, de vários ou de todos.

Portanto, o Estado tem em sua formação um conteúdo político, que permitirá posteriormente definir e delimitar o seu conteúdo jurídico. É a partir dessa ideia que Lassale (1987, p. 42) afirma que é com o desenvolvimento político do Estado que "reúnem-se os fatores reais do poder, dá-se-lhe expressão escrita e, a partir desse momento, não são simples fatores reais de poder, mas verdadeiro direito. Quem contra eles atentar, viola a lei e, por conseguinte é punido".

Como ensina Souza Jr. (2002, p. 45), existe uma relação intrínseca entre a sociedade e o político, sendo que inexiste um sem o outro.

A ligação entre o social e o político não é meramente acidental, no sentido de que possam ser separados, sem afetar a realidade de cada um desses elementos. Ao contrário, trata-se de uma relação essencial: não há o político sem a sociedade, nem a sociedade sem o político.

A problemática acerca do conteúdo político do Estado se desenvolve a partir de duas linhas específicas: a primeira delas, quanto à soberania desse caráter político do Estado, e em segundo lugar, em relação a sua dissonância quando posta ao lado do conteúdo jurídico-estatal.

É unânime a ideia de que em uma república democrática o poder soberano pertence ao povo, que de acordo com as instituições democraticamente construídas, exerce esse poder para que seus interesses e suas necessidades sejam atendidas.

Como bem ensina Paulo Bonavides (2012, p. 532) "a democracia existe, apenas, conforme se infere de toda essa formulação, se a vontade do povo tiver, sim, absoluto domínio e controle das faculdades de governo". Portanto, há nesse ponto o primeiro requisito que deve se atentar o Estado: o seu aspecto político deve ser o reflexo do regime a ser promovido.

Diante do regime totalitário, o conteúdo político do Estado será a base de fundamentação para esse totalitarismo, porquanto terá por função a de legitimar a concentração do poder soberano em relação à determinado grupo.

Nesse sentido escreve Souza Jr. (2002, p. 99):

Os regimes totalitários, por sua vez, intentam, como as democracias, fundamentar o Poder numa base social ampla, capaz de legitimá-las. Só que a titularidade do Poder não é reconhecida ú Comunidade, enquanto 
realidade existencial, mas a um setor abstraído da comunidade (por exemplo, uma dada classe social, uma dada "raça") ou a entidades ainda mais abstratas, elaboradas conceitualmente pelos ideólogos do regime, como a idéia de "nação".

A grande manifestação política do Estado está na escolha do regime político que orienta toda a atuação do ente estatal. Com isso, o regime político dependerá da relação entre "homem-Estado" existente. Quando o Estado é posto a serviço do homem, há então a construção de um Estado democrático politicamente; caso contrário, em que o homem é posto à serviço do Estado, se está diante de um regime totalitário.

Os diferentes modos que pode assumir o relacionamento homem-Estado constituem o que se denomina de sistemas políticos ou regimes de governo. Podemos classifica-los, hodiernamente, em suas linhas mais gerais, em dois grupos: ou o homem é colocado a serviço do Estado, ou o Estado é posto a serviço do homem. No primeiro caso temos os regimes totalitários; no segundo, os democráticos (SOUZA JR., 1978, p. 2)

Portanto, é possível afirmar pela existência de um caráter político do Estado, que para uma melhor compreensão de suas características, deve ser separado conceitualmente do Estado jurídico.

Essa separação viabiliza compreender as finalidades as quais se volta o Estado, bem como qual o regime político que o orienta, posto que o regime político guia e define os fins do poder do Estado.

Já nos referimos de passagem a regime político, como a encarnação concreta da ordem política, em seu dinamismo e segundo determinados princípios de organização referentemente às relações entre a Comunidade e o Poder. Em síntese: regime político é a organização política ou seja, uma combinação de fins, matéria e forma do Poder - vista em sua expressão concreta e numa perspectiva dinâmica. (SOUZA JR., 2002, p. 95)

Sendo a democracia o regime político pelo qual se orienta o Estado, o conteúdo político do ente estatal deve estar de acordo com a soberania popular, sob pena de sofrer com uma crise de legitimidade.

Além disso, a democracia plena pressupõe que o Estado político seja um reflexo do conteúdo jurídico-democrático que garante a forma do Estado. Significa dizer que o Estado político deve estar alinhado ao Estado jurídico, principalmente para que todas as ações desse Estado estejam justificadas e gozem de legitimidade.

Há, assim, a necessidade de que os dirigentes do Estado atuem de acordo com as normas constantes na Constituição jurídica desse Estado, o que confere a legitimidade necessárias à essas ações, conforme ensina Souza Jr. (2002, p. 96):

Revista do Direito [ISSN 1982-9957]. Santa Cruz do Sul, v. 1, n. 51, p. 3-35, jan./abr. 2017. https://online.unisc.br/seer/index.php/direito/index 
Os regimes democráticos, compreendendo os Estados Ocidentais que passaram pela evolução política do constitucionalismo liberal, descansam, quanto ao fundamento do poder, no princípio de que a titularidade última do mando pertence à Comunidade: uma realidade existencial, composta de uma pluralidade de grupos, classes, setores etc. ., com interesses, idéias e atitudes divergentes (consentimento ... aceitação). A Comunidade consentindo relativamente à Constituição que estrutura organicamente o Poder - delega funções às autoridades constituídas segundo as normas constantes da própria Constituição, de modo a conferir legitimidade à ordem assim estabelecida.

Por conta dessa relação é necessário analisar em que contexto se forma o Estado jurídico, bem como quais são as suas principais limitações frente ao Estado político.

\subsection{O ESTADO JURÍDICO}

Uma das principais características do Estado é o seu conteúdo jurídico. O conteúdo jurídico do Estado lhe garante uma forma, além de definir os seus objetivos.

A partir da construção teórica de Hans Kelsen, se torna possível sustentar a seguinte premissa: todo o Estado pode assim ser denominado por simplesmente possuir um conteúdo jurídico que lhe garante a forma de Estado, independente de qual seja esse conteúdo.

Então, a tentativa de legitimar o Estado como Estado "de Direito" revela-se inteiramente infrutífera, porque - como já foi acentuado - todo Estado tem de ser um Estado de Direito no sentido de que todo Estado é uma ordem jurídica. Isto não coenvolve qualquer espécie de juízo de valor político (KELSEN, 2009, p. 353).

Independente do seu conteúdo, a forma jurídica garante ao Estado a sua denominação enquanto Estado, o que permite separar, pelo menos a nível conceitual, o conteúdo jurídico do Estado e o conteúdo político do Estado, posto que a partir de Kelsen, não há uma vinculação direta entre estes que possa influenciar na caracterização do Estado enquanto Estado.

Não se pode negar que um Estado totalitário é um Estado, ao justificar a sua existência em um conteúdo jurídico que o institucionaliza, delimitando os seus fins.

Segundo o Direito dos Estados totalitários, o governo tem poder para encerrar em campos de concentração, forçar a quaisquer trabalhos e até matar indivíduos de opinião, religião ou raça indesejável. Podemos condenar com maior veemência tais medidas, mas o que não podemos é considera-las fora da ordem jurídica desses Estados (KELSEN, 2009, p. 353). 
Decorre que, ainda que autônomos, o Estado jurídico é a representação formal do Estado político, de modo que deve existir uma relação de similaridade entre esses dois polos, a fim de que exista um regime político pleno.

Significa dizer que a plenitude de um regime político depende da semelhança entre esses dois polos do Estado. No totalitarismo, o Estado possuirá à nível político e à nível jurídico o seu conteúdo voltado ao Estado total, em que o poder está concentrado e limitado à certas pessoas ou grupos. Na democracia, o Estado político se concretizará a partir da sua representação jurídica, estando esses dois polos voltados à garantir a soberania popular em relação ao poder, voltando o Estado aos interesses do povo, de acordo com as decisões do próprio povo.

Assim, o Estado jurídico complementa o Estado político, Ihe garantindo legalidade e legitimidade aos seus dirigentes. De outro lado, em regimes democráticos, a legalidade do Estado jurídico garante a impessoalidade do poder, já que está contida na lei a representação da vontade geral, em razão da qual estarão vinculados os representantes políticos. Essa característica é comentada por Paulo Bonavides, ao analisar as características do Estado constitucional.

Verifica-se, portanto, que a premissa capital do Estado Moderno é a conversão do Estado absoluto em Estado constitucional; o poder já não é de pessoas, mas de leis. São as leis, e não as personalidades, que governam o ordenamento social e político. A legalidade é a máxima de valor supremo e se traduz com toda a energia no texto dos Códigos e das Constituições (BONAVIDES, 2012, p. 43).

O Estado político modela o Estado jurídico, cabendo a este último uma figura de representação do conteúdo político-estatal, condensada, em sociedade, a partir de uma Constituição.

Como ensina SOUZA JR. (2002, p. 53), a ordem jurídica garante às relações políticas uma racionalidade, continuidade e regularidade, condensando e organizando o seu conteúdo.

A ordem jurídica desempenha uma função importantíssima quanto às relações políticas que regula. As relações políticas como elementos fáticos da ordem, são descontínuas e estão sujeitas a instabilidades e a violação de toda espécie. Só o direito, construção da razão humana, é capaz de Ihes dar continuidade, racionalidade e regularidade, sem o que nenhuma ordem política é possível.

A Constituição, dessa forma, é a representação do caráter jurídico do Estado, e de outro lado, é a organização formal do Estado político. Em democracias, onde o Estado político é composto pelas idealizações de um povo, o Estado jurídico e, por consequência, a Constituição, refletirá essas idealizações, além de delimitar a atuação dos representantes políticos de acordo com os ditames legais estabelecidos.

Sobre esse aspecto, escreve Souza Jr. (2002, p. 95):

Revista do Direito [ISSN 1982-9957]. Santa Cruz do Sul, v. 1, n. 51, p. 3-35, jan./abr. 2017. https://online.unisc.br/seer/index.php/direito/index 
A legitimidade racional é legal em virtude da combinação de duas situações ideológicas. A sociedade obedece (sociologicamente) os dirigentes, primeiro, porque eles assumiram e exercem o poder em conformidade com as regras estabelecidas na Constituição e nas leis. E, segundo, porque a Constituição e as leis que contêm essas regras básicas sobre o poder (obedecidas pelos dirigentes) decorrem - assim crê a sociedade - do assentimento racional de toda a sociedade.

Decorre que em democracias o Estado, tanto político quanto jurídico, deve estar precedido de legitimidade, de forma que o Estado político seja preenchido pelas idealizações populares, e o Estado jurídico represente essas exatas idealizações.

A ordem política, para ser democrática, deve passar no teste da legitimidade, ou seja: cabe à Comunidade julgar se o regime político sob o qual vive ou vai viver é democrático e, como tal, aceitável, segundo a representação do justo e do certo nela imperante. Assim, o Estado democrático requer um elemento subjetivo, existencial e essencialmente. Existencialmente, como qualquer regime, a democracia depende, para sua estabilidade, da adesão da Comunidade. Essencialmente, um regime só será democrático se os arranjos institucionais concretos que lhe dão forma, além de preencherem os requisitos objetivos do "modelo" democrático, forem aceitos pela Comunidade como tal (SOUZA JR., 2002, p. 110).

A legalidade passa a garantir a detenção do poder para o povo, pelo menos em relação ao Estado jurídico, como pode ser representado pela Constituição Federal brasileira, que garante em seu artigo $1^{\circ}$, parágrafo único, que "todo o poder emana do povo, que o exerce por meio de representantes eleitos ou diretamente, nos termos desta Constituição".

Com isso, a titularidade da comunidade em relação ao poder soberano é assegurada por intermédio do princípio da legalidade, conforme escreve Souza Jr.:

A titularidade da Comunidade é assegurada, então, pelo princípio da legalidade, vale dizer, pela submissão estrita das autoridades que exercem o mando ao império da Constituição e da ordem jurídica nela validada. A cornbinação da legalidade com a legitimidade constitui o Estudo de Direito democrático, que é garantido internamente (contra a própria autoridade legislativa) pela regra de que a lei deve ser igual para todos (princípio da igualdade) e, externamente, pelo controle jurisdicional praticado por um Judiciário independente (SOUZA JR., 2002, p. 97). 
A Constituição pode então ser vista como a formalização jurídica do Estado político, sendo que esta deve exprimir os objetivos e idealizações que orientam o Estado político, seja ele totalitário ou democrático.

A completude de um Estado depende da similaridade entre o Estado Político e o Estado jurídico e a Constituição. Como será desenvolvido adiante, eventual dissonância entre o Estado Político sob o qual vive uma sociedade, e o conteúdo jurídico pelo qual se orienta esse Estado, representa um grande problema para a conquista dos fins almejados socialmente.

Frente a esse fato que Ferdinand Lassale (1987, p. 55) salienta a importância de que, para que uma Constituição seja considerada como boa e possa ser duradoura, esta deve corresponder aos fatores reais do poder existentes em sociedade, ou seja, deve estar adequada a real situação na qual vive a população.

Quando se pode afirmar que uma Constituição é boa e duradoura? A resposta é clara e parte logicamente do que já consideramos: Quando essa Constituição escrita corresponder à Constituição real e tiver as suas raízes nos fatores do poder que refém o país. Onde a Constituição escrita não corresponder à real, surge inevitavelmente um conflito que não é possível evitar e, mais dia menos dia, a Constituição escrita, a folha de papel, sucumbirá forçosamente perante a Constituição real, a das autênticas forças vitais do pais.

A dissonância entre a Constituição ou o Estado jurídico e o Estado político leva à uma crise social, que impede que o regime político escolhido para orientar o Estado possa em algum momento ser pleno. Essa independência conceitual entre o político e o jurídico permite analisar o Estado detalhadamente, identificando seus limites e problemas.

\subsection{DEMOCRACIA JURÍDICA E TOTALITARISMO POLÍTICO}

A independência entre o caráter político e jurídico do Estado possibilita uma série de análises vinculadas a efetividade do regime político eleito para orientar determinada sociedade. Entre essas análises está aquela que questiona a extensão dessa separação conceitual para os próprios regimes. Vale examinar a possibilidade de dividir a democracia a partir de seu caráter jurídico e político, assim como também o pode ser feito em relação ao totalitarismo.

O Estado, em termos de compreensão conceitual, pode ser dividido em dois polos distintos: de um lado o caráter jurídico do Estado, que Ihe dá forma e representa o "dever ser" do ente estatal, já que delimita os caminhos a serem percorridos pelo Estado; e de outro lado o seu caráter político, que nos termos aqui propostos representa a atuação fática do Estado, em que o mesmo direciona os seus atos a fins previamente constituídos.

Revista do Direito [ISSN 1982-9957]. Santa Cruz do Sul, v. 1, n. 51, p. 3-35, jan./abr. 2017. https://online.unisc.br/seer/index.php/direito/index 
A necessidade de se realizar essa separação conceitual entre o direito e a política é mencionada por Georg Jellinek, que ensina que esses dois polos não se confundem, mas que, para a compreensão do direito, se mostra necessária uma investigação acerca da política.

Política e direito não podem confundir-se de modo algum, mas é preciso que se conservem seus respectivos limites; contudo não é possível fazer investigações eficazes de direito público sem um conhecimento do que é possível politicamente; ao não ter em conta essa consideração fundamental, o direito público se desviaria por caminhos perigosos e se converteria em uma disciplina puramente escolástica, alheio a vida e ao conhecimento do real (JELLINEK, 2000, p. 65).

A relação entre esses dois polos é de mútua troca: o Estado, em seu aspecto político, atua nos termos e objetivos do que dispõe o seu aspecto jurídico. Há, assim, uma garantia para a população, que ao eleger o seu ordenamento jurídico, representado por uma Constituição, como o reflexo dos seus anseios, tem por bem que o Estado cumpra o que está previsto juridicamente, viabilizando aos seus jurisdicionados que os direitos previstos lhes sejam garantidos.

A relação com a democracia é similar: se o Estado, em seu contexto político, se orienta pela democracia, assim como faz em seu aspecto jurídico, se torna possível defender a plenitude do regime democrático, viabilizando que a população usufrua das inúmeras benesses desse regime, sem qualquer limitação política ou jurídica de direitos inerentes à própria democracia.

Contudo, a relação "jurídico-político" nem sempre é harmônica. É nesse exato ponto em que reside o problema que influi diretamente na supremacia do direito e na efetivação da democracia.

Tal problema se dá em razão do fortalecimento do caráter político do Estado que, através dos seus agentes, pode utilizar a máquina estatal para fins que não representem os ideais democráticos juridicamente previstos.

Antes do "direito" está o "político", que emerge não só no direito, mas em todas as estruturas sociais. Com o político está o poder de regular o direito e, de certo modo, limitá-lo, afetando diretamente a sua supremacia.

É nesse aspecto que, diante de Carl Schmitt, se tem que o poder político exerce uma grande influência no poder jurídico estatal e, de certa forma, o modula, adequando-o aos fins que lhe sejam convenientes.

No pensamento de Schmitt, não se compreende o direito como reprodução automática das competências normativas. O direito é situacional. O poder é maior que o seu momento normativo. Para Schmitt, ao contrário do pensamento de Kelsen, não há identificação entre Estado e direito. Na visão kelseniana, a competência do poder estatal é a competência que formalmente as normas Ihe atribuem. Para Schmitt, o fenômeno do poder é maior que o do direito. Por isso, a guerra, a exceção, a ditadura, o caso 
extremo, revelam a verdade jurídica, não contida nos limites da norma jurídica (MASCARO, 2013, p. 61).

Contudo, nesse ponto reside um problema. Se o poder político modula a aplicabilidade do poder jurídico, de acordo com os fins que Ihe sejam adequados, há então uma afetação de ideias, como o republicanismo e a democracia, tuteladas pelo direito através da Constituição.

Ou seja, existe uma contradição, já que a democracia e a supremacia do direito pressupõem que o poder político tenha suas ações vinculadas ao poder jurídico, atuando em nome e nos limites do direito. Quando o poder político ultrapassa os limites do poder jurídico, surge uma crise de legitimidade desse poder, que passa a atuar de forma contrária às normas constitucionais.

Resta afetada, a partir de então, a força normativa da Constituição, tão propagada por Konrad Hesse, segundo o qual, a Constituição torna-se efetiva a partir do seu cumprimento:

\begin{abstract}
Embora a Constituição não possa, por si só, realizar nada, ela pode impor tarefas. A Constituição transforma-se em força ativa se essas tarefas forem efetivamente realizadas, se existir a disposição de orientar a própria conduta segundo a ordem nela estabelecida, se, a despeito de todos os questionamentos e reservas provenientes dos juízos de conveniência, se puder identificar a vontade de concretizar essa ordem. Concluindo, pode-se afirmar que a Constituição converter-se-á em força ativa se fizerem-se presentes, na consciência geral - particularmente, na consciência dos principais responsáveis pela ordem constitucional -, não só a vontade de poder (Wille zur Macht), mas também a vontade de Constituição (Wille zur Verfassung) (HESSE, 1991, p. 21).
\end{abstract}

Tanto a Constituição quanto o próprio direito têm a suas forças afetadas, que se enfraquecem quando o poder político excede os limites da democracia.

Diante do cenário traçado, em que a força do direito depende da observância dos limites impostos ao poder político, surge um questionamento de fundamental importância para que o direito, a democracia e a Constituição tenham sua supremacia respeitada: seria viável afirmar que a democracia jurídica não possui a capacidade de limitar o poder político, de modo que exista até mesmo a possibilidade de que se institua um totalitarismo político, ainda que sob a vigência de uma Constituição democrática?

Questionamento similar é realizado por Norberto Bobbio, ao investigar a possibilidade de sobrevivência da democracia em uma sociedade não democrática:

Daí a pergunta que melhor do que qualquer outra caracteriza a atual fase de desenvolvimento da democracia nos países politicamente mais democráticos: "É possível a sobrevivência de um Estado democrático numa sociedade não democrática?" Pergunta que também pode ser formulada deste modo: "A democracia política foi e é até agora necessária para que um povo não seja governado despoticamente. Mas é também suficiente?" 
Até ontem ou anteontem, quando se queria dar uma prova do desenvolvimento da democracia num dado país, tomava-se como índice a extensão dos direitos políticos, do sufrágio restrito ao sufrágio universal; mas sob este aspecto todo desenvolvimento ulterior não é mais possível depois que o sufrágio foi em quase toda parte estendido às mulheres e em alguns países, como a Itália, o limite de idade foi diminuído para dezoito anos. Hoje, quem deseja ter um indicador do desenvolvimento democrático de um país deve considerar não mais o número de pessoas que têm direito de votar, mas o número de instâncias diversas daquelas tradicionalmente políticas nas quais se exerce o direito de voto. Em outros termos, quem deseja dar um juízo sobre o desenvolvimento da democracia num dado país deve pôr-se não mais a pergunta "Quem vota?", mas "Onde se vota?" (BOBBIO, 1987, p. 156).

Diante dessa problemática se desenvolvem questionamentos relacionados às possibilidades de coexistência em um Estado, entre a democracia em âmbito jurídico, e de outro lado, uma atuação não democrática dos agentes políticos, em completa contradição com o regime democrático previsto.

Além disso, é viável afirmar que a democracia jurídica tem as forças devidas para impedir uma política totalitária? É possível afirmar que a democracia jurídico-formal que represente o conteúdo de um Estado, apesar de necessária, não é suficiente, pela exata razão da existência de um sistema político que, a depender dos seus interesses, pode "contrariar" as bases democráticas até então postas e impostas pelo e para o Estado.

Caso o sistema político encontre a consecução dos seus interesses em horizontes que não estejam vinculados à democracia, o sistema jurídico democrático passa a ser ineficaz, dando espaço para que um Estado totalitário entre em cena.

Dessa construção é possível questionar: o fato de que um Estado totalitário possa surgir diante das ações e interesses de um sistema político é capaz de destituir do sistema jurídico desse Estado o seu conteúdo democrático? Não necessariamente.

O conteúdo jurídico-democrático do Estado ainda continuará existindo, sendo que eventualmente será aplicado. Porém, nesse caso, as forças político-ditatoriais desse Estado se sobrepõem à democracia, demonstrando a fragilidade da democracia jurídico-formal, quando a democracia não se reflete no caráter "político" do Estado.

A aplicação de normas e preceitos democráticos passa então por um juízo de conveniência, através do qual o poder político totalitário avaliará se utiliza ou não da democracia para a consecução dos seus interesses. Com isso, apresenta-se o problema da instrumentalização da democracia pelo poder soberano, que delimitará a fruição da democracia de acordo com os momentos em que julgue ser do seu interesse.

Observa-se que, com isso, a supremacia do direito resta completamente afetada, posto que o sistema jurídico será visto pelos agentes políticos do Estado não como um limite de atuação, mas como um meio para atingir fins que contrariem a própria noção de democracia. 
A partir dessa ideia, surge a necessidade de avaliar os meios pelos quais se possa impedir essa tendência de divergência entre o Estado político e o Estado jurídico, com uma consequente análise em relação aos instrumentos existentes para a limitação do Estado e dos seus agentes.

\section{A DEMOCRACIA COMO LIMITE E FUNDAMENTO DO ESTADO}

Inquestionavelmente, a democracia é um valor a ser protegido, pois, além do necessário cumprimento à Constituição, cuja opção se deu pela construção de um Estado democrático de direito, se tem que a democracia precisa ser defendida, sobretudo, pela sua ideal adequação social, que melhor harmoniza a relação Indivíduo/Estado/Sociedade.

Nesse sentido, ressalta-se a lição de Cezar Saldanha Souza Junior, para quem a democracia política permite que a sociedade encontre a forma mais justa de conciliação entre interesses individuais e coletivos:

Vista sob este ângulo, a democracia política se torna necessária à efetivação do solidarismo, eis que passa a funcionar como o instrumento legítimo, capaz de permitir à própria comunidade encontrar a forma mais justa de conciliação entre o interesse individual e o interesse coletivo, entre a ação particular e a estatal, das quais a integração harmônica constitui a essência do ideal solidarista (SOUZA JR., 1978, p. 10).

O fortalecimento da democracia em seu aspecto político é o que se reivindica diante do problema da dissociação entre o "jurídico/político". Uma democracia política fortalecida, representativa de uma supremacia do direito, se dá com o controle sobre o Estado, a fim de que o mesmo limite a sua atuação de acordo com as finalidades democráticas.

Um Estado democrático em sua completude deve ser aquele em que as demandas populares sejam atendidas, ainda que não correspondam às vontades dos agentes políticos envoltos no papel de representar o povo, como ensina Dalmo de Abreu Dallari:

Um dos elementos substanciais da democracia é a prevalência da vontade do povo sobre a de qualquer indivíduo ou grupo. Quando um governo, ainda que bem intencionado e eficiente, faz com que sua vontade se coloque acima de qualquer outra, não existe democracia. Democracia implica autogoverno, e exige que os próprios governados decidam sobre as diretrizes políticas fundamentais do Estado (DALLARI, 2013, p. 303).

O alerta quanto ao perigo de uma democracia política enfraquecida é realizado por Paulo Bonavides, segundo o qual, o Estado, que é uma instituição de domínio, pode ser manipulado por governantes com uma vocação autoritária, de modo que os fins do Estado se encerrem em si mesmo. 
O Estado, que, em si, por sua natureza mesma, já é uma organização de domínio, pode, sob o leme de governantes ambiciosos e de vocação autocrática, destituídos de escrúpulos, converter-se em aparelho de abusos e atentados à liberdade humana, o qual exploraria, no interesse de sua força e de seu predomínio, aquela dependência básica do indivíduo, transformando, então, em mero instrumento dos fins estatais. É o que se dá com o Estado social do totalitarismo (BONAVIDES, 2014, p. 201).

A limitação do Estado não mais se resume às antigas visões do liberalismo, que pretendiam limitar o Estado apenas para a defesa de direitos individuais. Por lógico, essa limitação também é necessária. Contudo, se mostra necessário que a atuação do Estado seja limitada não apenas para a garantia de direitos individuais, mas, ainda, para que o mesmo cumpra os seus fins democráticos.

Essa limitação surge em duas vias: a primeira, de caráter material, com a criação de mecanismos de controle da população sobre a atividade do Estado; e a segunda, de caráter formal, com a criação ou otimização de estruturas para melhor organizar o poder estatal.

Como bem ensina Cezar Saldanha Souza Junior, a ausência de mecanismos que tivessem a utilidade de defesa do regime democrático, resultou nas manifestações totalitárias do século passado.

A ausência de valores afirmativos (e de instrumentos correspondentes), que habilitasse a autodefesa - inclusive jurídico constitucional - do regime democrático dos ataques inimigos, foi a primeira das causas do inverno totalitário que cobriu a Europa Ocidental civilizada no século passado (SOUZA JR., 2002, p. 101).

Portanto, analisar a democracia atual é pensar nos meios de efetivá-la, obrigando que o Estado, através dos seus agentes, cumpra os preceitos constitucionais.

A limitação do Estado em seu aspecto material ou de conteúdo se refere àquela em que haja um controle popular efetivo sobre a atuação do Estado, que se dá, apenas, com o fortalecimento da democracia direta.

Isto porque, a democracia direta representa uma forma de fortalecimento da democracia política, como escreve Paulo Bonavides, ao analisar o homem da democracia grega, concluindo que esse homem era integralmente político.

Demais, o homem da democracia direta, que foi a democracia grega, era integralmente político. O homem do Estado moderno é homem apenas acessoriamente político, ainda nas democracias mais aprimoradas, onde todo um sistema de garantias jurídicas e sociais fazem efetiva e válida a sua condição de "sujeito" e não apenas "objeto" da organização política (BONAVIDES, 2011, p. 293). 
De outro lado, em seu aspecto formal, questiona-se a suficiência dos mecanismos existentes, que objetivam limitar ou organizar a atuação do Estado.

Cita-se o modelo adotado em relação à divisão de poderes ou mesmo o modo como se deu a incorporação do federalismo no Brasil. Há uma evidente influência do modelo de divisão de poderes adotado sobre o enfraquecimento da democracia política no país.

Lembra-se, com apoio de Bonavides (2012, p. 44) que "o princípio da separação de Poderes traçava, por indução, raias ao arbítrio do governante, em ordem a prevenir a concentração de poderes num só ramo da autoridade pública".

Se, mesmo com a aplicação da tripartição dos poderes, adotada pelo ordenamento jurídico pátrio, existe espaço para que o Estado, em seu aspecto político, atue de forma arbitrária, em descompasso com o ordenamento jurídico, se mostra necessário investigar a efetividade desse modelo adotado.

Ainda, é preciso que se discuta a aplicação do federalismo como meio de fortalecer a democracia política e, por consequência, o direito. Nesse aspecto, importante ressalva é feita por Carlos Eduardo Dieder Reverbel, que ressalta a importância do federalismo para a construção do Estado Constitucional, fortalecendo a democracia.

Dentre os princípios supracitados ressalta-se o princípio federativo, pois desempenhou importante papel na construção de um Estado Constitucional. O federalismo primou pela descentralização política, fortaleceu a democracia, o pluralismo político e social. Estabeleceu um campo de relações mais amplo, respeitando a variedade regional e reforçando a política das minorias e das comunidades menores no exercício do poder, sentimento verdadeiro e natural do princípio da subsidiariedade (REVERBEL, 2008, p. 103).

Posto que a democracia deve ser fortalecida tanto no seu aspecto jurídico, quanto político, discutir as formas pelas quais se possa alcançar esse fortalecimento é essencial, verificando-se a validade das premissas até então construídas e a eficácia dos mecanismos propostos.

\subsection{A SEPARAÇÃO DOS PODERES}

A separação dos poderes ou de funções do Estado pode ser considerada como técnica de limitação do Estado, através da imposição de barreiras para a atuação dos seus agentes. Ou seja, a partir do estabelecimento de normas constitucionais que determinam as respectivas funções dos agentes políticos do Estado, cada um desses agentes deverá atuar de acordo com os limites previstos na Constituição.

Como ensina Manoel Gonçalves Ferreira Filho, não há necessariamente uma divisão do poder, posto que este é uno; o que existe é uma divisão de funções, por intermédio de uma estruturação dos órgãos que compõem esse poder.

Revista do Direito [ISSN 1982-9957]. Santa Cruz do Sul, v. 1, n. 51, p. 3-35, jan./abr. 2017. https://online.unisc.br/seer/index.php/direito/index 
Não há, nem pode haver, Estado sem poder. Este é o princípio unificador da ordem jurídica e, como tal, evidentemente, é uno. O exercício desse poder pelos órgãos estatais pode ser, todavia, diferentemente estruturado. Tanto pode ser ele concentrado nas mãos de um só órgão, como pode ser dividido e distribuído por vários órgãos. A unidade de exercício do poder, ou sua concentração como se usa dizer, foi a sua primeira forma histórica. A monarquia absoluta é disso o exemplo clássico. À luz da experiência, porém, essa concentração aparece inconve-niente para a segurança do indivíduo, por dar a alguém a possibilidade de fazer de todos os outros o que the parecer melhor, segundo o capricho do momento. Embora tenha ela a vantagem da prontidão, da presteza de decisões e de sua firmeza, jamais pode servir à liberdade individual, valor básico da democracia representativa. A necessidade de prevenir o arbítrio, ressentida onde quer que haja apontado a consciência das individualidades, leva à limitação do poder, de que a divisão do poder é um dos processos técnicos e, historicamente, dos mais eficazes (FERREIRA FILHO, 2012, p. 62).

Ocorre a repartição do exercício do poder político, impedindo que quaisquer dos órgãos estatais atue de forma completamente livre e arbitrária, em descompasso com as delimitações previstas na Constituição.

Conforme escreve Gargarella, o sistema de "freios e contrapesos" assegura uma série de filtros dentro de um processo de decisão, garantindo maior racionalidade no processo de produção das leis, bem como em seu conteúdo:

Obviamente, são muitas as virtudes que podem ser associadas ao sistema de "freios e contrapesos". Fundamentalmente, tal esquema assegura a presença de múltiplos filtros dentro do processo de tomada de decisões políticas: por um lado, tais filtros dificultam a aprovação de leis "apressadas"; por outro, favorecem a possibilidade de que as mesmas se enriqueçam com novos aportes. A primeira das virtudes mencionadas celebremente defendida por George Washington frente a um cético Thomas Jefferson- permite um saudável "esfriamento" das decisões: as iniciativas de lei devem se "pensadas duas vezes" antes de resultarem aprovadas (GARGARELLA, 2006, p. 178).

A partir do texto constitucional do Brasil, se verifica a opção pela separação dos poderes, definindo que as funções estatais se dividem entre o Executivo, Judiciário e Legislativo. A disposição do artigo $2^{\circ}$ da Constituição Federal do Brasil é clara, ao determinar que "são Poderes da União, 
independentes e harmônicos entre si, o Legislativo, o Executivo e o Judiciário". Portanto, definiu-se pela separação dos poderes, de forma que se optou pelo modelo da tripartição dos poderes.

O modelo tripartido dos poderes ou funções do Estado tem por origem a clássica teoria defendida por Montesquieu, segundo a qual é necessário a imposição de freios e contrapesos em relação ao poder, evitando a tirania e promovendo a liberdade.

Quando numa só pessoa, ou num mesmo corpo de magistratura, o poder legislativo se acha reunido ao poder executivo, não poderá existir a liberdade, porque se poderá temer que o mesmo monarca ou o mesmo senador criem leis tirânicas para executá-las tiranicamente. Não existirá também liberdade quando o poder de julgar não se achar separado do poder legislativo e do executivo. Se o poder executivo estiver unido ao poder legislativo, o poder sobre a vida e a liberdade dos cidadãos será arbitrário porque o juiz será o legislador. E, se estiver unido ao poder executivo, o juiz poderá ter a força de um opressor. Tudo então pereceria, se o mesmo homem, ou o mesmo corpo dos principais, o dos nobres, ou o do povo, exercesse esses três poderes: o de criar as leis, o de executar as resoluções públicas e o de julgar os crimes e as questões dos particulares (MONTESQUIEU, 2012, p. 191).

O modelo de tripartição dos poderes instituído pelo ordenamento pátrio tem uma função bem definida: organizar a atuação dos Estados, e, sobretudo, limitar a sua atuação. Com isso, institui-se o modelo dos freios e contrapesos, mencionado por Montesquieu, que tanto contribuiu com o tema.

Contudo, é preciso se ter a ciência de que o modelo de divisão dos poderes, propagado por Montesquieu em seu espírito das leis não é o único. A divisão dos poderes do Estado, ou, partindo-se de uma denominação mais correta, a divisão de funções do Estado, parte desde uma bipartição dos poderes, que restringe a divisão dos poderes do Estado em relação ao poder legislativo e ao poder judiciário, até mesmo em teorias que propagam a hexapartição dos poderes, em razão da qual se confere uma análise mais apurada.

Inicialmente, se tem a bipartição de poderes, que surge como possível solução para os problemas derivados da unidade geral dos poderes ou funções do Estado. Como marco teórico, pode ser citado John Locke, que em seu "Dois Tratados do Governo", faz referência à dois poderes distintos do Estado: o Poder Legislativo e o Poder Executivo.

Porém, como as leis elaboradas de imediato e em pouco tempo têm força constante e duradoura, e requerem uma perpétua execução ou assistência, é necessário haver um poder permanente, que cuide da execução das leis que são elaboradas e permanecem vigentes. E assim acontece, muitas vezes, que sejam separados os poderes legislativo e executivo (LOCKE, 1998, p. 515). 
Contudo, em razão da necessidade de um controle das leis produzidas pelo Poder Legislativo, bem como da necessidade de existir um controle sobre a atuação do Poder Executivo, se mostrou necessário a divisão do Estado, com a criação de outro órgão para contrabalancear esses poderes, que no caso, é o Poder Judiciário.

Como referencial teórico clássico para questão, pode ser citado Montesquieu, que lidera, em seu "Espírito das Leis", a ideia de separação de funções, em que o Rei possuía o controle do Poder Executivo, o Parlamento, sobre o Poder Legislativo, e a terceira via proposta, que era a dos juízes, com a função judiciária.

Já a tetrapartição de poderes vem a incorporar um quarto elemento nesses polos de "divisão das funções estatais": a separação governamental do Estado. Essa corrente, tendo como uma de seus maiores expoentes Benjamin Constant, que acredita que o Poder Executivo concentra duas funções que não podem ser confundidas, quais sejam, a de Chefia do Estado e a Chefia do Governo.

Posteriormente, tem-se a concepção de que o Estado comporta, ainda, outra divisão, que em tese se faz necessária, que é aquela que tem por fim a de separar a administração do Estado, de modo que a administração possa ter a autonomia em relação aos outros poderes.

Ao final, tem-se a hexapartição dos poderes, propagada por Ackerman, que bem crê pela necessidade de criação de outra função autônoma: a do Tribunal Constitucional.

Todas essas teorias se voltam ao mesmo objetivo: limitar a atuação do Estado, a fim de que os seus governantes não ultrapassem a sua esfera de competência.

A necessidade dessa limitação é inegável, posto que a mesma serve como forma de defesa da democracia, cumprindo salientar que umas das principais causas do enfraquecimento da democracia se dá por conta da inexistência ou ineficiência de instrumentos ou instituições que garantem a força constitucional, como ensina Cezar Saldanha Souza Junior (2002, p. 101).

A evolução dos modelos de separação dos poderes mostra que, quanto mais complexa a sociedade, mais necessário se torna organizar as funções do Estado, de modo que se garanta a adequada atuação dos agentes estatais.

Ainda, a limitação do Estado tem por bem garantir a força normativa da Constituição, posto que os agentes estatais ficam vinculados às ações e finalidades dispostas no ordenamento pátrio.

Garante-se, por consequência, a supremacia do direito, tendo em vista que a atuação do Estado terá por finalidade a de alcançar os objetivos constitucionalmente e democraticamente eleitos, independente das vontades e interesses dos agentes estatais.

Portanto, se mostra necessária a discussão acerca da efetividade de cada um dos modelos apresentados, e a viabilidade de sua instituição, principalmente através de uma análise que reflita sobre o melhor modelo de limitação de poder, de modo que se evite a dissociação entre o Estado jurídico e o Estado político.

Antes de qualquer análise acerca da efetividade de um ou outro modelo de divisão dos poderes, é preciso ressaltar a necessidade de um controle da população sobre esses poderes, pois somente esta poderá verificar se a divisão ora existente de um ponto de vista formal existe na prática. 
Como escreve Souza Jr., é imperioso que existam instrumentos constitucionais que garantam a fiscalização dos poderes pela comunidade, sob pena de se tornarem inúteis as técnicas internas de limitação de poder.

Mas de nada adiantarão as técnicas meramente 'internas' de limitação de poder, como a da divisão tripartida dos poderes, se não forem criados instrumentos constitucionais que possibilitem uma fiscalização dos poderes pela própria comunidade, suprindo a falta daqueles recursos sociais e jurídicos encontráveis nos Estados Unidos e que permitem o funcionamento razoável das suas instituições democráticas (SOUZA JR., 1978, p. 69).

Diante do problema em questão, que se dá a partir da contraposição entre a existência de uma democracia jurídica, e de outro lado, a imposição de um totalitarismo, é necessário que se analise qual o modelo ou quais modelos de divisão de poderes melhor se adapta e limita os agentes estatais, visando que suas atuações se deem nos exatos termos que a Constituição e as leis Ihes permitem.

O primeiro resultado advindo dessa análise é que o enfraquecimento da democracia política se dá em um contexto em que a democracia jurídica não produz efeitos práticos. Com isso se quer dizer que a democracia, quando enfraquecida, se limita à sua existência jurídico-formal, sem a aplicação dos seus preceitos básicos.

Tal problema ocorre pela exata razão de que os agentes políticos do Estado não cumprem as normas democráticas existentes, de forma que as suas ações se formam em um contexto extrajurídico ou extra-democrático. A partir do momento que um agente político se omite no cumprimento de qualquer dos seus deveres, ou atua para além do que the cabe, este desvirtua a sua função do caminho democrático.

Convém afirmar, portanto, que a efetivação da democracia, em todos os seus polos, pressupõe que os agentes estatais estejam vinculados e cumpram as normas democráticas, estando elas previstas na Constituição ou em leis infraconstitucionais.

Por lógico, se verifica que as possibilidades de atuação dos agentes estatais não podem ser ilimitadas, sendo necessária a existência de instrumentos que imponham limites à essa atuação. Assim, não convém que haja um poder absoluto, concentrado numa só pessoa ou grupo, mas sim que exista uma divisão desse poder e das suas competências.

A imposição de limites para atuação do Estado e de seus agentes é pressuposto para a existência de uma democracia efetiva, sendo a separação dos poderes ou das funções do Estado mecanismo imprescindível para que os agentes estatais não extrapolem a competência a eles conferidas pela Constituição.

Como escreve Gilberto Bercovici, essa separação dos poderes não ocorre de forma total e absoluta, sendo que a oposição de Montesquieu se direcionou à concentração do poder em relação à uma só pessoa, o que acarretaria em tirania.

Revista do Direito [ISSN 1982-9957]. Santa Cruz do Sul, v. 1, n. 51, p. 3-35, jan./abr. 2017. https://online.unisc.br/seer/index.php/direito/index 
Além disso, a própria Constituição da Inglaterra, exemplo utilizado por Montesquieu, não consagrava a separação total e absoluta dos Poderes. $\mathrm{O}$ que Montesquieu afirmou reiteradamente é a sua oposição à concentração de todo o poder nas mãos de uma só pessoa, que caracterizaria a tirania (BERCOVICl, 2004, p. 16).

A partir de então, se passa a analisar os modelos de divisão dos poderes, realizando as necessárias críticas, nos limites do objeto em estudo: a efetivação da democracia.

A primeira análise se volta ao modelo de bipartição dos poderes. Por certo, a concentração da função judiciária, seja no Poder Executivo ou no Legislativo, ocasionaria numa concentração tirânica de poder, diante da inexistência de autonomia para se verificar eventuais ilegalidades cometidas.

Em relação ao modelo tripartido da separação dos poderes, um dos mais usuais e atualmente aplicado na República brasileira, as críticas devem ser mais ponderadas do que as que se direcionam à divisão bipartida. Isto porque, a partir da divisão tripartida, deve se analisar os modelos por um critério de conveniência.

É inegável a importância da divisão tripartida de poder, pois a separação entre Executivo, Legislativo e Judiciário pode ser considerada como um marco na evolução da separação de poderes, sendo que equilibra nos devidos termos a criação, execução e aplicação das normas.

Contudo, não é um modelo isento de críticas. A influência de cada poder sobre os outros é um dos grandes problemas que afetam a própria ideia de divisão dos poderes.

Gilberto Bercovici ressalta a influência do Poder Executivo sobre os outros poderes, em razão da força da União no cenário federal, o que acaba, mesmo que indiretamente, influindo negativamente na separação de poderes existente.

O Poder Legislativo brasileiro é considerado sempre como inteiramente dependente do Poder Executivo e, consequentemente, submisso aos seus desmandos. A debilidade econômica da maior parte dos Estados perante a União faz com que se deduza a submissão do Congresso Nacional (formada por bancadas estaduais) à Presidência da República. Para Wanderley Guilherme dos Santos, ao contrário de boa parte dos analistas, é na medida em que os Estados se vêem indefesos diante do poder econômico da União que ganham maior relevância e efetividade os controles do Legislativo em relação ao Executivo. Com limitada autonomia e com capacidade tributária reduzida, os Estados só teriam em sua defesa a representação política no Congresso Nacional, utilizada como barganha para obter seus pleitos junto à Presidência da República (BERCOVICl, 2004, p. 88). 
A tripartição dos poderes é afetada pela distribuição desproporcional das próprias funções, advindas, inclusive, da desproporcionalidade da força da União, contrapondo-se à ideia de federação.

Manoel Gonçalves Ferreira Filho escreve acerca da interpenetração dos poderes, salientando que o próprio Montesquieu aceitava exceções ao princípio da separação, quando admitia a intervenção do chefe do Estado, pelo veto, no processo legislativo.

Por outro lado, ainda que se tome por científica a classificação de Montesquieu, resta indagar se a especialização que recomenda se realiza nos Estados modernos. O próprio Montesquieu abria exceção ao princípio da separação ao admitir a intervenção do chefe de Estado, pelo veto, no processo legislativo. A organização, todavia, dos três poderes na Constituição envolve sempre uma certa invasão de um poder na função reservada a outro. Assim é que o legislativo às vezes julga (p. ex., o Senado brasileiro, os crimes de responsabilidade do Presidente - art. 52, I, da Constituição de 1988) e não raro administra (p. ex., quando admite pessoal para a sua secretaria). Igualmente, o judiciário ora administra (v. g., quando um tribunal organiza o seu secretariado), ora participa da elaboração da lei (pela iniciativa de certos projetos - v. g., Constituição de 1988, art. 96, II), se é que não legisla pelas súmulas vinculantes (v. g., CF, com a EC n. 45/2004, art. 103-A). Enfim, o Executivo não raro legisla (formalmente pelas medidas provisórias ou pela delegação, informalmente por meio dos "regulamentos") e julga (no contencioso dito administrativo). A especialização inerente à "separação" é, dessa forma, meramente relativa. Consiste numa predominância no desempenho desta ou daquela função. Cada poder, em caráter secundário, colabora no desempenho de outras funções, pratica atos teoricamente fora de sua esfera (FERREIRA FILHO, 2012, p. 63).

Bruce Ackermann direciona as suas críticas aos modelos de separação de poderes, ressaltando a importância de se pensar em novos modelos de separação de poderes.

Quase três séculos depois, já passa da hora de repensar a santíssima trindade de Montesquieu. Apesar de seu status canônico, ela nos mantêm cegos para o surgimento, em nível mundial, de novas formas institucionais que não podem ser categorizadas como legislativas, judiciárias ou executivas. Embora a tradicional fórmula tripartite falhe ao capturar os modos característicos de operação de tais formas, essas unidades novas e funcionalmente independentes estão desempenhando um papel cada vez mais relevante em governos modernos. Uma "nova separação de poderes" está emergindo no século XXI. A compreensão de suas características 
distintivas requer o desenvolvimento de um modelo conceitual que contenha cinco ou seis categorias - ou talvez mais. E, assim, nós devemos dar um carinhoso adeus a Montesquieu, para então criar novas bases para o direito administrativo comparado, que deem conta dos desafios dos governos modernos (ACKERMANN, 2014, p. 15).

Visualizando a incorreta sobreposição de forças do Poder Executivo sobre os outros poderes, apresenta-se a tetrapartição dos poderes, que possui como foco das suas críticas o modelo empregado pela tripartição dos poderes, ao verificar que o Poder Executivo, quando concentra na mesma pessoa a chefia do Governo e do Estado, afeta de forma geral a dinâmica da separação dos poderes.

Uma das principais características da tetrapartição dos poderes está em sua aproximação ao parlamentarismo, quando realiza a cisão do Poder Executivo entre a Chefia do Estado, representado pelo Rei ou Presidente da República, e a Chefia do Governo, exercido por um órgão coletivo, o conselho de ministro ou gabinete, e, atualmente, o primeiro-ministro.

Juridicamente, caracteriza-se o parlamentarismo pelos seguintes traços: 1) É um regime de divisão de poderes, na medida em que adota a distinção clássica das funções do Estado e sua atribuição a órgãos diversos. 2) Os Poderes Legislativo e Executivo, entretanto, são interdependentes. De fato, o governo depende, para manter-se no poder, do apoio da maioria parlamentar, que pode a qualquer instante, seja votando moção de desconfiança, seja rejeitando questão de confiança, obrigá-lo a apear-se desse poder, pondo em jogo a responsabilidade política. Por outro lado, o Legislativo, ou pelo menos a sua Câmara baixa, pode ser dissolvido pelo governo, convocando-se nova eleição. 3) O Executivo parlamentarista possui estrutura dualista. O rei, ou o Presidente da República, é o chefe de Estado, com funções de representação, de cerimonial e de conselho, enquanto o governo é exercido por um órgão coletivo, o conselho de ministros ou gabinete. Ultimamente, porém, à testa desse conselho vêm as Constituições pondo um chefe, o primeiro-ministro, presidente do conselho ou chanceler, verdadeiro chefe do governo (FERREIRA FILHO, 2012, p. 68).

Já a pentapartição direciona para um novo modelo de separação de poderes, incluindo a administração como poder autônomo. A Administração Pública se institucionaliza da forma imparcial, não se influenciando pelos direcionamentos ideológicos do governo. Guardada essa autonomia, a pentaparticiação leva ao surgimento do quinto poder político, que é o Poder Administrativo. Assim ensina Cezar Saldanha: 
Em segundo lugar, institucionalizou-se a imparcialidade da Administração Pública, formando, em seu conjunto, um órgão constitucional. Distinguiu-se a função administrativa da função de chefia de Estado e, também, da função estrita de governo, de modo que os órgãos administrativos pudessem guardar autonomia frente ao endereço ideológico dos governos. A técnica racionalizada que aí se adotou foi erigir o conjunto dos órgãos da Administração em poder político novo: o Poder Administrativo, o quinto poder político (SOUZA JR., 2002, p. 86).

A principal e mais visível vantagem da instituição do quinto poder político, através da garantia de autonomia à Administração está na possibilidade de que a mesma se posicione de modo indiferente ao conjunto ideológico emanado dos outros poderes, em especial, pelo Poder Executivo.

A contaminação exercida pelos poderes sobre a administração acarreta no desvirtuamento de suas funções, de modo que a administração passa a atuar não em favor das "regras do jogo", mas de acordo com os interesses individuais e escusos de determinada pessoa ou grupo.

A principal razão para se analisar e rediscutir os modelos de separação de poderes está na necessidade de que as "regras do jogo" da democracia sejam respeitadas, garantindo que os poderes se "autovigiem", evitando que os seus agentes atuem em descompasso com a democracia jurídica.

Cezar Saldanha ressalta a importância dessa neutralidade advinda do modelo da tetrapartição e pentapartição dos poderes:

O puncton saliens da arquitetura institucional dos poderes políticos poderia ser condensada na seguinte questão, percebida pelos três grandes (Weber, Kelsen e Schmitt): como construir uma ordem político-constitucional capaz de ser aceita por todas as forças, por todos os partidos e por todos os segmentos sociais, numa sociedade - como a alemã da segunda década do séxulo XX - cruamente pluralista, dividida em ideologias tão diferentes (comunistas, socialistas, conservadores, sociais-cristãs, liberais e reacionárias) e tão antagônicas entre si? A resposta encontrada pode ser divida em dois pontos. Em primeiro lugar, reafirmou-se, agora em contexto republicado, a distinção entre Estado e governo, que vinha das monarquias do século XIX, com o reforço da legitimidade do chefe de Estado (pela eleição direta por todo o eleitorado) e a atribuição expressa a este de poderes de arbitragem do jogo político. Com isso, assegurava-se uma instancia neutra e suprapartidária, devotada a moderar e arbitrar uma convivência democrática pacífica, legal e civilizada, na instancia governamental, das divergências ideológicas que opunham forças, partidos e seguimentos. Em outras palavras: diante das divergências ideológicas no plano governamental, ratificou-se a necessidade de uma área neutra de chefia de Estado, que estivesse comprometida exclusivamente com a 
garantia das regras do jogo e das regras sobre o jogo do processo político democrático (SOUZA JR., 2002, p. 86).

A atuação da administração tem por bem a neutralidade em suas ações, determinada a servir o interesse público, transcendendo os interesses dos seus agentes:

Administrar é função de serviço (o semantema min, do sânscrito, carrega esse sentido). É cuidar de um interesse de que não se é propriamente dono. Como dizia Cirne Lima, é a "atividade de quem não é dono, não é senhor". Com lealdade, eficiência e discrição, a Administração serve o legislador, serve o Judiciário e serve, 'principalmente, o governo do dia. Mas antes de tudo, serve, pelo direito, o interesse público mais elevado, que transcende o de seus agentes, ao qual se orientam também os demais poderes políticos (SOUZA JR., 2002, p. 89).

Portanto, os benefícios do modelo da pentaparticipação dos poderes estão diretamente vinculados à ideia de autonomia da Administração Pública sobre os demais poderes, possibilitando que a sua atuação não se direcione para finalidades que não estejam inseridas na Constituição, garantindo a supremacia do direito e da democracia, bem como em relação neutralidade dos agentes nas análises que realizam para que ao cidadão sejam garantidos os seus direitos.

A pentapartição dos poderes permitiu um aprimoramento das garantias à supremacia do direito, em pelo menos dois aspectos. No plano teórico, a racionalização formal da organização constitucional e da estrutura política, com sua componente lógico-formal, produziu a Teoria Contemporânea da Constituição, que se deve principalmente a Kelsen. Começa a vingar, em substituição a um direito dito político, materialmente indefinido $\mathrm{e}$ formalmente pouco consistente, um verdadeiro direito constitucional, coroando um ordenamento jurídico representado na metáfora de uma pirâmide. A ideia matriz daquela teoria e desse direito ganhou corpo na supremacia da Constituição, vista agora como uma supralegalidade dotada de força normativa própria. O impacto dessa doutrina sobre todos os campos do direito foi imenso (SOUZA JR., 2002, p. 100).

A dúvida que surge com a defesa da pentapartição dos poderes e da elevação da Administração Pública ao rol de poder político autônomo é a de que, sem vinculação direta com os outros poderes, essa autonomia da administração poderia acarretar em discricionariedades por parte dos seus agentes. Ou seja, quando não se vincula aos outros poderes, a Administração, e por consequência os seus agentes estariam desvinculados do controle atualmente exercido pelos demais poderes, para que a administração cumpra a sua função.

Revista do Direito [ISSN 1982-9957]. Santa Cruz do Sul, v. 1, n. 51, p. 3-35, jan./abr. 2017. https://online.unisc.br/seer/index.php/direito/index 
Contudo, é preciso lembrar que, em qualquer dos modelos de separação de poderes, inexiste autonomia absoluta dos poderes políticos. Assim como existe um controle da atividade do Poder Executivo, Legislativo e Judiciário, a fim de que estes atuem apenas nos limites impostos pela Constituição, assim também ocorreria com a Administração Pública, ao ser elevada ao patamar de poder político autônomo.

Por fim, a hexapartição dos poderes, que além da divisão já mencionada, acresce como poder político autônomo o Tribunal Constitucional. Desvinculado do Poder Judiciário, o Tribunal Constitucional assume sua natureza política enquanto poder autônomo.

A ideia do Tribunal Constitucional surge com Hans Kelsen, quando inicialmente situa uma "norma fundamental" a qual deve dirigir o sistema jurídico como um todo. Com isso, advém a necessidade da criação de um poder político autônomo, que garanta a defesa da norma fundamental em todos os seus parâmetros.

Hans Kelsen (1883-1970) é o idealizador e o primeiro doutrinador da instituição Tribunal Constitucional. A Constituição - concebida como conjunto normativo supremo, no ápice da estrutura jurídica, à qual todas as demais normas devem conforma-se, formal e materialmente - e um Tribunal Constitucional para garantir essa supremacia são os dois corolários principais de sua visão piramidal e escalonada do ordenamento jurídico (SOUZA JR., 2002, P. 112).

Como ensina Cezar Saldanha, a desvinculação do Tribunal Constitucional em relação ao Poder Judiciário acontece para que não ocorra uma politização indevida do Judiciário. Como descreve o citado autor, Kelsen formula essa separação em resposta à Carl Schmitt, quando este último afirma que se a proteção da constituição recair sobre o Poder Judiciário, através do Tribunal Constitucional, haveria essa politização indevida. Ressalta-se que, o que pretende Schmitt, ao realizar essa crítica, é que passe ao Chefe de Estado (Poder Executivo) o dever de ser o guardião da constituição.

Contudo, Kelsen rebate as críticas de Schmitt, o afirmar que nada impede que o Poder Executivo atue em defesa da Constituição, mas apenas não concorda que este seja o seu único guardião. Ainda, afirma que o Tribunal Constitucional não deve integrar o Poder Judiciário, evitando, assim, a sua politização, devendo se constituir como poder autônomo, além de não ver diferença entre legislação e aplicação do direito.

Primeiramente, nada impede que, de alguma forma, o chefe de Estado possa agir como defensor da Constituição: Kelsen não concorda é que seja o único. Segundo - o Tribunal Constitucional não deve integrar o poder judiciário, mas constituir-se em um poder político independente de todos os demais poderes. Terceiro, Kelsen não vê diferença de natureza entre legislação e aplicação do direito. Não seria, pois, absurdo denominar a 
função desse Tribunal de jurisdição. E contra-ataca de forma letal e profética: o que realmente destruirá a democracia é entregar os elevados poderes de defender a Constituição a um chefe de Estado que, pelo menos na prática da Constituição de Weimer, nada mais tem que de poder neutro, pois, cada vez mais, domina a política da República, inclusive o seu poder governamental (SOUZA JR., 2002, p. 115).

Ressalta-se as palavras do próprio Kelsen, na defesa de um tribunal constitucional autônomo enquanto poder político, atuando na defesa da constituição.

O órgão legislativo se considera na realidade um livre criador do direito, e não um órgão de aplicação do direito, vinculado pela Constituição, quando teoricamente ele o é sim, embora numa medida relativamente restrita. Portanto não é com o próprio Parlamento que podemos contar para efetuar sua subordinação à Constituição. É um órgão diferente dele, independente dele e, por conseguinte, também de qualquer outra autoridade estatal, que deve ser encarrego da anulação de seus atos inconstitucionais - isto é, uma jurisdição ou um tribunal constitucional (KELSEN, 2013, p. 150).

A defesa da Constituição e do cumprimento das normas emanadas pela mesma representa condição primordial para que a democracia jurídica se converta em objeto a ser aplicado diariamente, garantindo que o plano político também corresponda à democracia.

Portanto, a democracia plena pressupõe a existência de instituições que garantam o cumprimento de seus preceitos, como ocorre com o Tribunal Constitucional.

Contudo, é preciso lembrar que a mera existência de instituições não garante o cumprimento das normas constitucionais e o respeito à democracia. Como escreve Cezar Saldanha (1978, p. 172) "não existe forma de governo perfeita, pois é materialmente impossível criar um sistema absolutamente livre de crises, de abusos e de conflitos".

Nesse ponto parece residir a contigência de todas as formas de organização de poderes. Por mais aperfeiçoada e cuidadosa que ela pretenda ser, haverá sempre um 'ponto cego' infiscalizável e incontrolável, mesmo quando se tratar de comunidade forte e consciente de seus direitos em face do Estado. Talvez aqui se encontre a prova mais cabal da imperfeição das sociedades humanas no campo político e que radica, afinal, na imperfeição do próprio homem: não existe forma de governo perfeita, pois é materialmente impossível criar, um sistema absolutamente livre de crises, de abusos e de conflitos. Por melhor estruturada que seja a organização política, sempre haverá um campo onde a vontade dos dirigentes prevalece livre de mecanismos de controle, para o bem ou para o 
mal. A missão dos modeladores de instituições políticas, assim, não consiste em buscar forma de governo perfeita, mas a menos imperfeita, ou seja, aquela que, reduzindo ao mínimo possível a esfera de conduta política irresponsável, possa, ainda, condicioná-la ao bem comum, através da previsão de cautelas e de condições adequadas (SOUZA JR., 1978, p.172).

Verifica-se que a análise não se presta a escolher o melhor modelo de separação de poderes, mas sim para que, nas condições atuais da sociedade, se possa verificar qual modelo melhor se adequa às necessidades sociais.

\subsection{O FEDERALISMO}

Outro instrumento que tem por objetivo a imposição de limites à atuação dos agentes estatais é o federalismo, que realiza uma distribuição de competências entre entes federativos, que são autônomos em suas atuações.

A imposição de limites aos agentes estatais foi uma das principais razões da criação do federalismo, impondo uma divisão das competências entre os entes federativos.

Roberto Gargarella, ao comentar sobre o legado federalista advindo da promulgação da Constituição dos Estados Unidos, lembra que uma das preocupações daqueles que pensavam na instituição do federalismo nos Estados Unidos era o de impedir que grupos majoritários, movidos por paixões e interesses que não correspondiam às necessidades de toda a comunidade, conseguissem desvirtuar a função a eles garantidas, acarretando em um governo tirânico.

Tomando como eixo o trabalho de Madison, pode-se advertir que a primeira preocupação que acometia o político virginiano era a de conter a ação daqueles que ele chamava de "grupos facciosos": fundamentalmente, grupos majoritários que, movidos por interesses ou paixões comuns, atuavam contrariamente aos interesses da comunidade ou dos direitos dos cidadãos. Desse modo, Madison concentrava sua atenção, muito especialmente, num dos grandes riscos enunciados à época: o risco da tirania das maiorias, manifesto com particular gravidade nos anos prévios à Constituição (GARGARELLA, 2006, 175).

O Estado Federal tem por característica que cada Estado-Membro tenha autonomia, para que atue nos limites impostos pela própria Constituição, sem a interferência indevida dos outros membros da federação.

No caso da Constituição da República do Brasil, há uma intensa manifestação do federalismo em sua formação. Desde seu início há a consolidação de que a partir daquela Constituição, se forma uma República Federativa, através da união indissolúvel de seus Estados Membros, quando em seu 
art. $1^{\circ}$ afirma-se que "a República Federativa do Brasil, formada pela união indissolúvel dos Estados e Municípios e do Distrito Federal, constitui-se em Estado Democrático de Direito".

É tão forte a inserção do ideal federalista na Constituição Brasileira de 1988 que a primeira barreira imposta pelo seu art. 60 , $\S 4^{\circ}$, que impede a reforma da Constituição através de emenda, se direciona exatamente para obstaculizar a abolição da forma federativa de Estado.

Como ensina Manoel Gonçalves Ferreira Filho, o federalismo garante que cada EstadoMembro goze de autonomia, possibilitando que estes possam se auto organizar, além de possuírem uma descentralização legislativa, administrativa e política.

O Estado-Membro goza de autonomia. Quer dizer, é livre no campo a ele deixado pela Constituição do Estado federal. Este, o Estado total, na sua soberania, fixa a organização do todo e ao fazê-lo cria um campo aberto para os Estados federados. Tal campo, como já se viu, tem um espaço mínimo: autoorganização, descentralização legislativa, administrativa e política. Observe-se que os Estados-Membros de um Estado federal podem ser a seu turno Estados federais ou Estados descentralizados (inclusive Estados constitucionalmente descentralizados). De fato, a Constituição do todo pode determinar que as Constituições dos Estados adotem a descentralização, o que importa em determinar a autonomia de entes intraestaduais (FERREIRA FILHO, 2012, p. 38).

A partir da análise a que se presta o presente trabalho, quanto à investigação de eventuais mecanismos que tenham por finalidade a limitação do livre arbítrio dos agentes políticos do Estado para a promoção da democracia plena, é possível afirmar que a concentração do poder, seja em uma pessoa ou grupo, seja em determinado ente, representa um óbice ao livre fluir da democracia política, haja vista que nesse caso existe um espaço muito amplo de liberdade no processo de tomada de decisões pelo governante, que sem as limitações e controles devidos, poderá atuar em descompasso com os preceitos da democracia jurídica.

Do ponto de vista interno, o federalismo não é apenas técnica que contrai o poder central a fronteiras intransponíveis e invulneráveis, ante as quais esbarra a autoridade do Estado federal. Não é unicamente princípio de organização, mas consectário mesmo daquelas ideias. Desde Montesquieu, tinham elas por escopo essencial abater o Estado, desconjuntar o Leviatã monstruoso do absolutismo, reprovar o poder, que a teoria política da burguesia costumava desprezar nas grandes épocas do passado (BONAVIDES, 2012, p. 206).

Importante, portanto, a divisão de competência entre os entes, sendo o modelo de Estado Federal um bom exemplo de como se deve limitar o poder para que se favoreça a democracia. 
Gargarella lembra que modelo de Estado Federal, muito por inspiração na Constituição dos Estados Unidos, foi copiado por diversos países. É o caso da América Latina, incluindo o Brasil.

Finalmente, fica claro também que o mecanismo elaborado pela Convenção Federal foi e continua sendo exportado, literalmente, para o mundo todo, e isso não apenas por uma fascinação irreflexiva com o modelo americano, mas também, em boa medida, pela certeza de que esse modelo inclui ferramentas institucionais dignas de serem reproduzidas. A América Latina em geral e a Argentina em particular constituíram-se em fiéis seguidoras do exemplo constitucional dos Estados Unidos. O modelo, em definitiva, contribuiu decisivamente ao desenvolvimento das democracias representativas, promoveu o equilíbrio de poderes como chave principal da Constituição; foi o detonante do modelo de "controle judicial das leis" (cada vez mais expandido no mundo) 13; representou um notável exemplo de como exercer o federalismo; e ilustrou o mundo acerca da importância de incorporar uma declaração de direitos no texto constitucional (GARGARELLA, 2006, p. 181).

Além de estabelecer a Federação, a Constituição Federal de 1988 garante descentralização do todo, isto é, além de organizar a União, prevê e reconhece os Estados e Municípios, como escreve Ferreira Filho:

A Constituição brasileira de 1988, no que segue a anterior, não se contenta em estabelecer a Federação, descentralizando o todo; estabelece também o municipalismo, impondo a descentralização das partes. Há em nossa Constituição três ordens e não duas, como é normal no Estado federal. Em primeiro lugar, a ordem central - a União - em segundo lugar, ordens regionais - os Estados - em terceiro lugar, ordens locais — os Municípios. A Constituição, com efeito, afora organizar a União, prevê e reconhece os Estados, dando-lhes competências e rendas, prevê e reconhece os Municípios, entidades intraestaduais, conferindo-lhes competências e rendas. Prevê o novo texto a auto-organização dos Estados e dos Municípios sujeitando-os ao respeito aos princípios constitucionais. Estes são os enumerados no art. 34, VII, ou seja: "a) forma republicana, sistema representativo e regime democrático; b) direitos da pessoa humana; c) autonomia municipal; d) prestação de contas da administração pública, direta e indireta; e) aplicação do mínimo exigido da receita resultante de impostos estaduais, compreendida a proveniente de transferências, na manutenção e desenvolvimento do ensino e nas ações e serviços públicos de saúde (acrescentado pela EC n. 29/2000)". Ganham os Municípios o 
poder de auto-organização, sujeitos, entretanto, aos princípios da Constituição Federal, aos da Constituição do respectivo Estado, além de estarem obrigados ao respeito a uma série de preceitos expressos, conforme o disposto no art. 29 da Constituição Federal. Isto corrobora a tese de que a Constituição de 1988 consagra um federalismo de segundo grau (FERREIRA FILHO, 2012, p. 39).

O problema que surge no Estado Federal se refere às discrepâncias existentes entre os entes federados, que impedem que no plano material exista uma real autonomia.

A relação de dependência entre os entes federativos, muitas vezes de natureza econômica, impede que estes consigam a autonomia que em tese é garantida. Com isso, há a sobreposição de um ente sobre o outro.

Para chegar à essa constatação, basta uma análise das deficiências que apresentam Estados e principalmente Municípios, que impedidos, na maioria das vezes por conta de uma baixa arrecadação, não conseguem viabilizar projetos de investimentos locais, impossibilitando que os cidadãos tenham acesso à direitos básicos.

Na realidade, a desproporcionalidade da representação popular na Câmara é reflexo dos desequilíbrios regionais. A dependência dos Estados em relação à União se manifesta nas repartições de receita e transferências de renda, que contribuem muitas vezes (como acontecia durante a ditadura militar) para que os Estados se tornem submissos à vontade do governo federal (BERCOVICI, 2004, p. 94).

Assim, é possível afirmar que o Estado Federal depende que exista uma adequada divisão de forças políticas e econômicas entre os entes federativos. Caso assim não ocorra, inexistirá uma limitação eficaz dos entes federados.

Como ensina Paulo Bonavides, é pressuposto da Federação a autonomia dos entes federativos, sendo que os Estados-membros devem ter a mesma força e serem protagonistas nas decisões relativas à Federação.

$\mathrm{Na}$ verdade, como assinala o constitucionalista João Mangabeira, há Federação onde a tutela constitucional garante a autonomia dos Estados, onde estes participam de competência constitucional própria, onde a Constituição não se reforma sem a audiência e o consentimento dos Estados-membros, onde, por último, acima da vontade dos componentes da organização política, paira uma instancia judiciária superior, tribunal supremo, com poderes para dirimir conflitos porventura suscitados entre a União e os referidos Estados (BONAVIDES, 2012, p. 200). 
Verifica-se que o Federalismo é instrumento de limitação do Estado que auxilia na promoção de uma democracia plena, haja vista que impede a concentração do poder, além de evitar o intervencionismo indevido nos Estados-membros, de modo que, de forma autônoma, cada Estado reconheça as suas necessidades, e assim possam construir os melhores caminhos para proporcionar à sua população o acesso aos direitos que lhe são atintes.

O federalista verdadeiro é aquele que se não aparta da realidade, não teme o intervencionismo em si mesmo, e escrupulosamente combate, e com razão, o desvirtuamento da prática intervencionista, a politização dos fins a que serve a intervenção do Estado. E não só a politização, senão também o favorecimento ilícito que essa intervenção prodigaliza a grupos econômicos e financeiros privilegiados. Atuando contra o interesse público, à sombra da proteção oficial, agravam a desigualdade econômica e ascendem na sociedade desunida as labaredas da injustiça social (BONAVIDES, 2012, p. 212).

O fortalecimento da democracia pressupõe a contenção da atuação dos agentes políticos, visando uma adequação das suas atitudes com as finalidades predispostas na democracia jurídica. $O$ federalismo pode ser considerado como mecanismo capaz de conter esse poder, possibilitando a conciliação entre democracia jurídica e democracia política.

\section{CONSIDERAÇÕES FINAIS}

A insuficiência do sistema jurídico para a existência de um verdadeiro Estado democrático leva ao pensamento sobre a fragilidade da democracia frente ao que Carl Schmitt denomina de "poder soberano". Sendo o Estado e mesmo o direito um mero instrumento para a concretização dos interesses do poder soberano, existe um espaço facilmente manipulável em que se possa instalar um Estado totalitário.

Quando se volta uma análise para a realidade social, em que se propagam diariamente injustiças sociais, que contrastam com as disposições e garantias constitucionais, se conclui que o sistema jurídico não consegue se vincular à realidade, principalmente pelos interesses políticos envolvidos.

Para a produção dessa análise realizou-se a divisão conceitual entre o Estado Jurídico e o Estado Político, tratados no primeiro capítulo do trabalho. Conforme se expôs, o Estado se forma a partir de uma base jurídica, quando se garante uma delimitação jurídica de sua existência, independente do seu conteúdo, o que pode ser indicado como Estado Jurídico. Em outro ponto, o Estado Político, também tratado no primeiro capítulo do presente trabalho, se desenvolve através da atuação dos seus agentes políticos, dando materialidade à conteúdo jurídico.

Como exposto, o Estado Político se desenvolve de acordo com o regime escolhido para the

dar uma direção: a democracia ou o totalitarismo. À princípio, a escolha do regime político

Revista do Direito [ISSN 1982-9957]. Santa Cruz do Sul, v. 1, n. 51, p. 3-35, jan./abr. 2017. https://online.unisc.br/seer/index.php/direito/index 
ocorre no âmbito jurídico do Estado, garantindo a vinculação dos agentes políticos a esse regime.

Contudo, a partir da crítica realizada no subcapítulo 2.3, foi possível verificar que inexiste uma vinculação entre o regime político previsto pelo Estado Jurídico e o regime existente no Estado Político. A explicação para tal fato está na possibilidade de que os agentes políticos desvirtuem o poder que o Estado Jurídico Ihes confere, contrapondo aos fins democráticos inicialmente previstos.

Diferenciar a democracia jurídica da democracia política passa a ser essencial, compreendendo que, enquanto a democracia jurídica institucionaliza a democracia política, esta última delimita a aplicação dos preceitos democráticos legalmente previstos, sendo possível até mesmo que o Estado político reprima a aplicação da democracia jurídica de tal modo que esta se torne inútil, possibilitando na instituição de um regime totalitário frente ao Estado político.

Exsurge a partir disso a necessidade da imposição de instrumentos que limitem a atuação dos agentes estatais, não apenas para a proteção de direitos individuais, mas sobretudo para que se cumpra às regras do jogo democrático.

Assim, no segundo capítulo se analisou os diversos modelos de separação de poderes, expondo as características e divisões de cada modelo, ao final se concluindo que a separação dos poderes é essencial para a democracia, contudo, o melhor modelo para a plenitude democrática depende das condições existentes em sociedade.

Ainda no segundo capítulo se desenvolveu uma análise sobre o federalismo, concluindo que o Estado Federal é importante para a contenção do livre arbítrio dos agentes estatais. Porém, a má distribuição de forças entre os entes federados impossibilita um real federalismo, com entes autônomos e independentes, e, por consequência, impossibilita uma adequada limitação do Estado.

A consciência de tal processo leva à construção de alternativas que visem fortalecer a democracia em sua completude, com o fortalecimento do acesso popular ao Estado e ao direito, a fim de que haja um controle constante sobre a atuação estatal na observância dos preceitos democráticos.

\section{REFERÊNCIAS}

ACKERMANN, Bruce. Goodbye, Montesquieu. rda - revista de Direito Administrativo, Rio de Janeiro, v. 265, p. 13-23, jan./abr. 2014.

ALVES, Fernando de Brito. Constituição e Participação Popular. Curitiba: Juruá, 2013.

. Democracia à portuguesa. Rio de Janeiro: Lumen Juris, 2014.

BERCOVICl, Gilberto. Dilemas do Estado Federal Brasileiro. Porto Alegre: Livraria do Advogado, 2004.

BOBBIO, Norberto. O futuro da democracia: Em defesa da democracia. 6. ed. Rio de Janeiro: Editora Paz e Terra, 1997.

BOBBIO, Norberto. Estado, Governo, Sociedade: por uma teoria geral da política. 14. ed. São Paulo: Editora Paz e Terra, 2007.

BONAVIDES, Paulo. Ciência Política. 18. ed. São Paulo: Malheiros, 2011.

Revista do Direito [ISSN 1982-9957]. Santa Cruz do Sul, v. 1, n. 51, p. 3-35, jan./abr. 2017. https://online.unisc.br/seer/index.php/direito/index 
BONAVIDES, Paulo. Do Estado Liberal ao Estado Social. 11. ed. São Paulo: Malheiros, 2014.

BONAVIDES, Paulo. Teoria Geral do Estado. 9. ed. São Paulo: Editora Malheiros, 2012.

BRASIL. Constituição (1988). Constituição da República Federativa do Brasil. Brasília, DF: Senado, 1988.

DALLARI, Dalmo de Abreu. Elementos de Teoria Geral do Estado. 32. ed. São Paulo: Saraiva, 2013.

FERREIRA FILHO, Manoel Gonçalves. Curso de Direito Constitucional. 38. ed. São Paulo: Saraiva, 2012.

GARGARELLA, Roberto. Em nome da constituição. O legado federalista dois séculos depois. Em publicacion: Filosofia política moderna. De Hobbes a Marx Boron, Atilio A. CLACSO, Consejo Latinoamericano de Ciencias Sociales; DCP-FFLCH, Departamento de Ciencias Politicas, Faculdade de Filosofia Letras e Ciencias Humanas, USP, Universidade de Sao Paulo. 2006

HESSE, Konrad. A Força Normativa da Constituição. Porto Alegre: safe, 1991.

JELLINEK, Georg. Teoría general del Estado. México: FCE, 2000.

KELSEN, Hans. Jurisdição constitucional. 3. ed. São Paulo: Editora WMF Martins Fontes, 2013.

KELSEN, Hans. Teoria Pura do Direito. 8. ed. São Paulo: WMF Martins Fontes, 2009

LASSALE, Ferdinand. O que é uma Constituição Política. São Paulo: Global Editora, 1987.

LOCKE, John. Dois tratados sobre o governo. São Paulo: Martins Fontes, 1998.

MASCARO, Alysson Leandro. Introdução ao Estudo do Direito. 4. ed. São Paulo: Atlas, 2013.

MONTESQUIEU, Charles de Secondat. Do Espírito das Leis. Rio de Janeiro: Saraiva, 2012.

REVERBEL, Carlos Eduardo Dieder. O Federalismo numa Visão Tridimensional do Direito. 2008. 137f. Dissertação (Mestrado em Direito). Universidade Federal do Rio Grande do Sul, Porto Alegre, 2008.

SCHMITT, Carl. O Conceito de Político. Rio de Janeiro: Editora Vozes, 1992.

SCHMITT, Carl. Legalidade e Legitimidade. Belo Horizonte: Del Rey, 2007.

SCHMITT, Carl. Teología Política. Madrid: Trotta, 2009.

SOUZA JUNIOR, Cezar Saldanha. A crise da democracia no Brasil: aspectos políticos. Rio de Janeiro: Forense, 1978.

SOUZA JR., Cezar Saldanha. O Tribunal Constitucional Como Poder: uma nova teoria da divisão dos poderes. São Paulo: Memória Jurídica Editora, 2002.

\section{COMO CITAR ESSE DOCUMENTO:}

ALVES, Fernando de Brito; SANTOS, Yago Aparecido Oliveira. Democracia e totalitarismo: anotações sobre democracia, separação dos poderes e federalismo. Revista do Direito, Santa Cruz do Sul, v. 1, n. 51, jul. 2017. ISSN 1982-9957. Disponível em: $<$ https://online.unisc.br/seer/index.php/direito/article/view/7897>. Acesso em: doi:http://dx.doi.org/10.17058/rdunisc.v1i51.7897. 